\title{
Small Industry Resolution Growth Through the Readiness for Using Android Technology in the Industrial Revolution 4.0
}

\author{
A. Eliyana*, M. Mashud, A.R. Sridadi, R.J. Sunarsono, E.S. Pradikta \\ Universitas Airlangga \\ Surabaya, Indonesia \\ *wahyu_saputra76@yahoo.com
}

\begin{abstract}
Industrial Revolution 4.0 as the stage of technology influences many sectors include financial sectors like small medium enterprises. This study aims to discuss some significant SMEs' variables and explore the readiness of small industry sellers to the new way of marketing such as the use of android phone. To establish the accuracy, some SMEs' sellers from across difference regions in East Java, Indonesia are taken to take apart to this study. Some findings are found like the intention to market reviews their products via android application are big but Reviews those are not matching with reviews their effort, some SMEs' sellers found feel satisfied with what they have now, some SME's sellers are waiting for real action of the related party actively guiding for them to face this era, and many more.
\end{abstract}

Keywords-SMEs; Readiness; Android; Technology

\section{INTRODUCTION}

2017 became the year that is quite stressful for the micro small and medium enterprises (SMEs) and entrepreneurs of small and medium industrial sector (SMEs) in Indonesia. On December 31, 2015 is the beginning of where the AFTA (ASEAN Free Trade Area) came into effect in which the boundary between one country and other countries were increasingly invisible. This is a point where the government should be able to empower all elements of Indonesian SMEs in order to compete in the domestic and global environment.

The Government through the Bank Indonesia Regulation Number 17/12 / PBI / 2015 for the renewal on the previous regulation, namely No. 14/22 / PBI / 2012 is a regulation that is so positive for the micro, small and medium enterprises (SMEs) which contains the financial assistance for the provision credit or financing by commercial banks. This indicates that when MSMEs want to obtain financial assistance from banks in the form of loans then they should be bankable or meet eligibility requirements set by the banks.

However, this regulation seems very contradictory if we look at the facts, as quoted from the website kabarbisnis.com which states that

"Deputy Finance data allow the ministry said, nationally, the total SMEs in the first and second clusters which are micro-enterprises are vulnerable financing reached 50.70 million units. a total of 35.49 million, or $70 \%$ of the business is a business that is not worth the effort and bankable, so it has a high risk of return of capital. the remaining 15.21 million or $30 \%$ of businesses have a decent business (feasible) but not yet bankable. nationally, the total MSMEs which include first and second clusters that are difficult to access financing reached 50.70 million units. "

Given this reality, this certainly is a fact that very concern which at the same time also SMEs have to survive the onslaught of many products from other countries when AFTA enforced. Seeing this, the study is aimed at providing the best solution to be able to create conditions in which the human resources of SMEs, especially SMEs which focus on the food sector in East Java and Indonesia in general awareness and knowledge of eligibility (feasible) in its business and the feasibility of banking aspects (bankable).

This study is a continuation of the previous year's study with a survey method that can be identified in-depth about the obstacles faced by SMEs in the food sector meet business feasibility aspects (feasible). Besides other output from the first year of study resulted in android application technology in accordance with the needs of food producers as android application user named "SMEs Gate". It was decided to change the name of the application that originally was "All Ways - Smart Application" to "SMEs Gate". Changes due to the application name evaluation and analysis of the survey results feedback some entrepreneurs, will be easily identified by the SMEs food as one of the users of these applications are derived from diverse backgrounds. This application will be a bridge between SMEs foods with potential investors who will invest in businesses that are considered to have a high prospect through initial assessment with an extensive profile of the SME. Not just end there, this application will also have its own space that serves as the marketing of MSME products to the general public where the tool is also able to integrate with a variety of social media such as Facebook, Twitter, Instagram and others.

In this study where the study has entered the second year will continue the development and improvement in the application "SMEs Gate" and one of the programs that will be implemented in this application is the empowerment of SMEs 
food on the feasibility of aspects of banking (bankable) integrated with the institution partnered with researchers. The focus in the second year is the execution of the program that has been designed to the SMEs of food through seminars and training of human resource development at the final stage is a periodic evaluation. Location of the study to be selected is the province of East Java who represent the face of SMEs in Indonesia.

Based on all the above considerations, this study is entitled: Human Resources Development Program Literacy Financial Feasibility (Feasible) and Feasibility Banking (Bankable) At Actors SMEs East Java Provincial Food Through the implementation of "All Ways - Smart Application".

\section{LITERATURE REVIEW}

\subsection{Micro small medium enterprises (SMEs)}

According to Law No. 20 of 2008 on micro, small and medium enterprises Micro Enterprises criteria are (1) Having a maximum net worth IDR 50,000,000.00 (fifty million rupiahs), excluding land and buildings; (2) It has annual sales results IDR300,000,000.00 (three hundred million rupiah).

While the Small Business criteria are (1) It has a net worth of more than US $\$ 50,000,000.00$ (fifty million rupiah) up to at most IDR 500,000,000.00 (five hundred million rupiah) not including land and buildings; (2) It has annual sales of more than IDR300,000,000.00 (three hundred million rupiah) up to a maximum of IDR 2,500,000,000.00 (two billion five hundred million rupiah)

Criteria described to Medium Business (1) Having a net worth of more than US \$500,000,000.00 (five hundred million rupiah) up to a maximum of IDR 10,000,000,000.00 (ten billion rupiahs), excluding land and buildings; (2) It has an annual sales turnover of more than USD 2,500,000,000.00 (two billion five hundred million rupiah) up to a maximum of IDR 50,000,000,000.00 (fifty billion rupiah).

According to the Chamber of Commerce and associations as well as small businesses association, also the criteria of bank Indonesia, then include the category of small businesses are: (1) Business Trading is the agency, the retailer, the export or import and others with an active capital companies (MAP) does not exceed 150,000 .000 / year and capital turnover (CTO) or capital turnover does not exceed IDR. 600.000, -; (2) Farming: agriculture and plantations, land or sea fishery farms and other businesses including the scope of the supervision department of agriculture. Conditions such as MAP and CTO Issuer trading business; (3) manufacturing businesses are metal or chemical industries, food or beverage, mining, minerals and various other small industries to limit MAP = IDR 250.000.000, - and the boundary CTO = IDR $1,000,000,000,-;$ (4) The business that sells services to thirdparty service personnel, consultants, planners, overhaul, transport as well as restaurants and other points to the limits of MAP and CTO as trade and agriculture above; (5) business services, construction, namely building contractors, electrical road, bridge irrigation and businesses - other business related to building construction engineering, with a limit of MAP and CTO as industrial businesses.

\subsection{Feasible}

According to [1] defined that the Feasibility Study is an activity to assess the extent of the benefits that can be obtained in carrying out a business activity or project and is a material consideration in making a decision, whether to accept or reject the idea of a planned business or project. Understanding feasible in this assessment is the possibility of a business idea or project to be implemented to provide benefits, both in terms of financial benefits and in terms of social benefit.

The feasibility study is an activity to analyze, assess and research various specific aspects of a business idea or project to be implemented or have been implemented, thus giving an idea worthy (feasible-go) or not feasible (no feasible-no go) a business idea or project when viewed of the resulting benefits of the project or business idea that either of shrinkage of financial benefits and social benefit. Whether or not a business is determined through careful analysis, a systematic and thorough review of the factors or aspects that may affect the likelihood of success (Kay) implementation of ideas that will be implemented or attempted to be run.

The purpose of each is to conduct a feasibility study assessment of a business or project idea. The assessment is then analyzed and evaluated or compared to the good or the ideal included compared to the goals to be achieved, the requirements and standards should buy. [2], that to prepare a feasibility study carried out assessment of several aspects, among others aspects of marketing (marketing), technical aspects of the production, management aspects, environmental aspects and financial aspects.

\section{$2.3 \quad$ Bankable}

Bankable is a common term in the field of banking which means that meets the requirements of the bank. When filing the loan application to the bank, or a request for financing to Islamic banks. Bank will deliver the requirements that must be met by potential customers. Generally a Bankable said business, if the business can meet the criteria required by the bank or the business meets the requirements of the bank after analyzing the incoming request with $5 \mathrm{C}+3 \mathrm{R}$ method.

$5 \mathrm{C}$ is an abbreviation of Character (moral), Collateral (additional collateral), Capital (equity morale / attempt), Capacity (ability to pay), Condition (productivity). While 3R stands for Return (results to be obtained), repayment (ability to pay) and Risk (risk). $5 \mathrm{C}+3 \mathrm{R}$ are guidelines that are held by banks and other financial institutions as the application of the precautionary principle (Prudent) before approving a credit application or financing of prospective customers.

Bankable SMEs are characterized by (1) has had an adequate formal legality device; (2) management of tidier; (3) sufficient market access; (4) the presentation of financial information can be received as per the requirements of technical bank; (5) access to information and knowledge of banking products is quite extensive; and (6) guarantees (collateral) can meet the requirements of the technical bank. The second group is SMEs that unbankable group, which is characterized by (1) has not had a formal legality adequate; (2) management has not neat; (3) limited market access; (4) the presentation of financial information not meet the technical 


\subsection{Public achievement}

Achievement in general is to raise the community's economy through the empowerment of SMEs through the application of the application "SMEs Gate".

4.2 Specific achievements

Here are the achievements of a more specific representation of the general achievement set by the researchers:

a. Provide an overview and information about the condition of food SMEs in East Java.

b. Providing solutions that can be used as guidelines and new considerations for the provincial government of East Java and the Indonesian government in general in order to increase and development of human resources SMEs Food in fulfilling aspect feasible and bankable and in order to face domestic competition and the global higher through the implementation of the application "SMEs Gate".

c. Through this research is expected to be able to print the community as SMEs food with human resources that are superior and more aware of the technologies that have high competitiveness in the face of domestic and global competition.

d. The results of this study can be used as consideration for further research.

4.3 Strategic steps

After determining the outcomes that are more specific, the researchers lowered it back into programs that are represented into strategic steps to be taken by the researcher. Here are the steps that will be a strategic step by researchers:

a. Digging factors that hinder the fulfillment aspect feasible and bankable on food SMEs in East Java province.

b. Create and develop applications "SMEs Gate" as one of the latest solutions empower SMEs in food is also a representation of the solution to the obstacles experienced in this sector that are temporarily focused on the area of East Java.

c. To disseminate to users of the application "SMEs Gate" which is able to be used as a solution to their business development.

This study used a qualitative approach. The population in this study are all SMEs in East Java meal with a range of numbers 6,852,694 SMEs [3]. This study uses a case study approach with some procedures concluded [4]. In this study, the researchers decided to take a sample of the research that food SMEs in the province of East Java by one of the organizations that participated under the auspices of the Department of Cooperatives and SMEs in East Java province named Cooperative Trading House (CTH). Since account is a member CTH informants in each town in the province of East Java.

\section{RESULTS}

Based on the objectives and benefits of the research that has been mentioned before, it can be described that the implementation of application program "SMEs Gate" was presented to the SMEs in several destinations. d. Coordinate with relevant government applications "SMEs Gate" will be developed.

e. Conducting periodic evaluation of the applications developed.

\subsection{Data search process}

In the implementation of this study, researchers are finding information about food SMEs in East Java. As has been mentioned earlier researchers, researchers focused sampling Cooperative members MSMEs food Trading House East Java province. Determination of CTH group as a sample in this study was not achieved easily. Researchers initially experienced problems in finding enough sample, this is because researchers have found difficulty in determining the criteria for SMEs food will be entered into the study sample.

4.5 Outcomes achieved

Based on the study design that was previously set, then this section will explain the outcome of researchers established by 
the researchers. Outcomes in the first year and is also a product of this research is application-based Online Shopping cell phone which researchers named "SMEs Gate". Here is an explanation of the online shopping application "SMEs Gate" which is an outcome researchers. SMEs Gate is a android based smart application that will we dedicate to the advancement of SMEs in East Java in particular, also SMEs throughout Indonesia in general. The phenomenon of the background for us to make this smart application is due to see the potential of SMEs is so big in the market. East Java has a very large number of SMEs. Based on the amount of data held by the Department of Cooperatives and SMEs in East Java province, said that the number of SMEs in East Java is as much as 6,825,931 SMEs spread into sectors such as agriculture, mining and quarrying, manufacturing, electricity, gas and water, construction, trade, hotels and restaurants, transport, financial sector, as well as other services sectors. Trade, hotel and restaurant itself has a considerable number of SMEs which reached 1,720,042 SMEs. Seeing this amount, it will be separated opportunity for researchers to be able to develop the SME sector of the food. We ourselves know that Indonesia has a rich variety of foods so much. Indonesia has a lot of food menus, ranging from mild to severe food meals. This potential is tremendous potential if it can be developed. One way that these food products from SMEs can flourish and known to the public, then we can use one of the marketing strategies that marketing mix. The marketing mix is a set of marketing tools tactical controlled are: product (product), price (the price), place (where), and promotion (promotion) that the company match to be able to get a response from consumers as desired by the company [5].

More specifically in the context of this study, researchers will use the place (where) as a strategy in marketing products of food SMEs in East Java province. The place is the variety of activities the company that made the product available to consumers [5]. One marketing tool that can researchers use for products to be owned by the manufacturer are available for consumers is to provide a place where the products are owned by the manufacturer can be seen by kosumen. More specifically, this place can be an application, which this program will greatly help both the producers and consumers to interact with each other regardless of time and place.

Based on research planning since the beginning, the researchers use research tool is an application which researchers named "SMEs Gate". Application of SMEs Gate is a smart application that can display the products that are owned by the SMEs of the food. This application will be able to become a place for food SMEs and consumers to interact. Specifically interaction is expected here is in the form of buying and selling activity. From the consumer side, the positive value that is owned by the consumer is a consumer can see a variety of products owned by SMEs food and also simultaneously contribute to the development of SMEs the food itself. Then, when viewed from the aspect of manufacturers, Gate SMEs this application has a lot of positive values such as SMEs who acts as a manufacturer can market its products. In addition they will also be more educated with the latest technology such as mobile phones and the internet, it is the researchers revealed because some of the SMEs are also a people who are already quite old and also have low education levels so that through this application they will be more educated. Another positive values that are owned SMEs Gate application made by the researchers will continue to undergo development in various aspects, one of which is this application will be able to provide a calculation of a variety of products that have been sold. Products that have been sold will be processed in such a way so as to produce a simple financial report which is owned by the researcher. These financial statements will be one of the items that can help SMEs to fulfill aspects of food bankable.

\section{CONCLusions}

Based on research conducted from February to August 2017, researchers found a lot constraints experienced by SMEs in East Java province. Among the constraints experienced by SMEs to researchers mentioned as follows:

1. The government is giving attention to SMEs in East Java province, but in the view of some businesses, there are still quite a lot of things that government should do for the development of SMEs in East Java province. An example is the ease in handling MUI Halal certification, BPPOM, etc.

2. Governments provide more intensive training, such as training and debriefing enhancement technology, information, marketing briefing, debriefing financial, human resource development and so forth. This is also coupled with the facilities to follow training such as accommodation, transport and others.

3. The government in this case the Department of Cooperatives and SMEs provide empowerment to the institutions under its umbrella such as Cooperative Trading House $(\mathrm{CTH})$, in this case the value is less active researchers in several aspects such as aspects of renewal of information on the Internet.

4. Government empowers SMEs by providing more provide the tools needed by SMEs as engines and others. There was also more active role in the assess the needs of SMEs, especially the owner is elderly.

5. The government can focus on CTH activities and also helped to make CTH can perform activities coordinated transactions between sellers and buyers to create an institution that is recognized by the government as Cooperative

\section{REFERENCES}

[1] Chim, Y.-C., Kassim, AA and Ibrahim, Y. (1998), "Dual classifie system for handprinted alphanumeric character recognition", Pattern Analysis and Applications, Springer, Vol. 1 No. 3, pp. 155-162.

[2] Ibrahim, yacob, 1998 .Studi Kelayakan Bisnis. Edisi Pertama: Rineka Cipta, Jakarta

[3] klinikumkmjatim.com based on data from the Department of Cooperatives and SMEs in East Java

[4] Creswell, JW, Hanson, WE, Clark Plano, VL and Morales, A. (2007), "Qualitative research designs: Selection and implementation", The 


\section{PRESS}

Counseling Psychologist, CA Sage Sage Publications: Thousand Oaks,

CA, Vol. 35 No. 2, pp. 236-264.

[5] Kotler, Philip dan Gary Armstrong.(2010). Principles of Marketing. 13th Edition.Prentice-Hall, Inc. New Jersey 